\title{
Bacterial Pathogens from Bile and their Antimicrobial Sensitivity Pattern in a Tertiary Care Hospital
}

\author{
S.D. Naik*, A.S. Wyawahare and M.H. Bhalchandra \\ Department of Microbiology, MGM's Medical College and Hospital, Aurangabad, India \\ *Corresponding author
}

A B S T R A C T

\begin{tabular}{|l|}
\hline Ke y w o r d s \\
Bile, Antimicrobial \\
sensitivity pattern.
\end{tabular}

The bile is a lipid-rich sterile solution produced in the liver. Infection of biliary tract may occur in many conditions due to breakdown of human defence mechanisms and it is associated with post-operative complication that may prolong hospital stay hence present study was undertaken to detect the bacterial pathogens from bile and their antimicrobial sensitivity pattern. To study antimicrobial susceptibility pattern of organisms isolated from bile specimen and to know common pathogens isolated from bile during study period. To establish empirical therapy for biliary tract infection in our hospital, all the bile specimen received in Microbiology Department for culture and sensitivity were included in study. These specimens were processed as per standard protocol. Relevant patient data was collected. Prospective observational study six months, in this study period total 57 samples were studied Out of which 7 were sterile, in 34 samples single bacterial pathogen was grown and in 16 samples more than one bacterial pathogen was grown. Most common organisms isolated were Escherichia coli and Pseudomonas aeruginosa.

\section{Introduction}

The bile is a lipid rich sterile solution produced in the liver. Infections of biliary tract may occur in many conditions due to break down of human defence mechanism during surgery or endoscopy.

The presence of bacteria may be associated with the presence of any foreign body inserted in the biliary system such as a biliary catheter. The bacteria may come through haematogenic path. ${ }^{2,3,4}$ Obstruction to the biliary duct due to any reason leads to increase in the pressure in the biliary duct and which will lead to cholangitis. $^{2,3,4}$ The presence of these bacteria in the gallbladder may lead to malignant epithelial transformation. ${ }^{6,7,8}$
Bactibilia is associated with higher postoperative infectious complications due which there is prolonged hospital stay, need for antibiotics based therapy and higher cost. $^{9,10,11}$

Widespread and indiscriminate use of antibiotics over the years has altered the sensitivity pattern of microorganisms which necessitates a change in empiric antibiotic policy. ${ }^{12,13,14}$

In our area scanty information is available on bactibilia, hence the present study was undertaken to detect the bacterial pathogen from bile and their AST pattern. 
The main aim of this study an antimicrobial susceptibility pattern of organisms isolated from bile specimen. And also to know common pathogens isolated from bile during study period. Also to formulate empirical therapy for biliary tract infection in our hospital.

\section{Design}

Prospective observational study.

\section{Study period}

Six months

\section{Materials and Methods}

The present study was carried out in a tertiary care hospital. After approval from ethical committee the study was started.

Inclusion criteria: All the bile samples received in the department of Microbiology for culture and sensitivity were included in the study.

Exclusion criteria: Repeat isolate from the same patient were excluded.

These samples were from the patients with various biliary diseases. Out of which the most common is choledochocholethiasis. These specimens were processed as per standard protocol. ${ }^{15}$ Samples were inoculated on blood agar and MacConkey agar plates and incubated at $37^{\circ} \mathrm{C}$ for $24 \mathrm{hrs}$. Next day the organisms are seen for the colony morphology on blood agar and MacConkey agar plates. Organisms were identified by gram stained smears and biochemical tests. Suitable Vitek card was selected and the growth was processed in the Vitek 2 compact system for identification and AST pattern.

In this study total 57 samples were processed and data was analysed.
If there is growth of single organism, it is called monomicrobial and if there is growth of two or more than two, it is called as poly microbial sample.

For gram negative organisms, the bacteria resistant to two or more classes of antibiotics, including the beta-lactum antibiotics during the microbiological examination and antibiogram were considered to be a multidrug resistant bacteria. ${ }^{16}$

\section{Results and Discussion}

Out of 57, 38 patients were from more than 50 age group $(66.66 \%)$ (Table 1$)$.

Out of these 57 samples, 50 samples showed growth.

34 samples were monomicrobial and 16 samples were polymicrobial.

Total 67 isolates are identified.

Out of 67 isolates 65 isolates were Gram negative $(97.01 \%)$ and 2 were gram positive (2.98\%) (Table 2).

The most common bacterial pathogen isolated were Escherichia coli $(\mathrm{n}=26,38.80 \%)$ and Pseudomonas aeruginosa $(\mathrm{n}=25,37.31 \%)$, followed by two pathogen each of Acinetobacter baumanii, Acinetobacter junii and Sphingomonas paucimobilis (Table 3).

One isolate each of Proteus mirabilis, Klebsilla pneumoniae, Enterococcus faecium, Enterococcus species, Comamonas testestroni, Stenotrophomonas maltophilia, Cupravidus pauculosus, Aeromonas hydrophila, Enterobacter aerogenes, Achromobacter xylosoxidans was isolated.

Biliary obstruction causes an increase in ductal pressure, resulting in bacterial proliferation and dissemination. 
Bacterial infection is the most common type of acute cholangitis, which can range from mild to life threatening with a Gram-negative preponderance. ${ }^{16}$ Endoscopic treatment to enable biliary drainage and the use of antibiotics is the main stay of treatment for this condition. ${ }^{17,18,19}$

Bactibilia is associated with higher postoperative infectious complications due which prolonged hospital stay, need for antibiotics based therapy and higher cost. ${ }^{9,10,11}$ Widespread and indiscriminate use of antibiotics over the years has altered the sensitivity pattern of microorganisms which necessitates a change in empiric antibiotic policy. ${ }^{12,13,14}$ In our study the most common organism was E. coli $(38.80 \%)$ which is in concordance with that of below mentioned studies by Malik et al., Alves et al., Manan F et al., Sahu et al., ${ }^{20,21,22,23}$ Pseudomonas aeruginosa was the $2^{\text {nd }}$ most common isolate $(37.71 \%)$ which is higher than the other studies. ${ }^{20,21,22,23}$

The sensitivity of E. coli to Amikacin, Gentamicin, Trimethoprim/Sulfametoxazole, imipenem and Ertapenem is $84 \%, 53.84 \%$, $57.69 \%, 53.84 \%$ and $50 \%$ respectively. All E. coli were susceptible to Tigecycline (Table 4).

Table.1 Total 57 samples are studied. Out of which 29 were from male and 28 were from female patients

\begin{tabular}{|l|l|l|}
\hline Age of patient & Male & Female \\
\hline $0-30 y r s$ & 5 & 3 \\
\hline $30-50$ & 6 & 5 \\
\hline Above 50 & 18 & 20 \\
\hline Total & 29 & 28 \\
\hline
\end{tabular}

Table.2 Out of the 65 Gram negative isolates 17 isolates were MDR (multidrug resistant)

\begin{tabular}{|l|l|}
\hline Name of MDR isolate & Number \\
\hline Escherichia coli & 10 \\
\hline Pseudomonas aeruginosa & 5 \\
\hline Sphingomonas paucimobilis & 1 \\
\hline Acinetobacter baumanii & 1 \\
\hline Total & 17 \\
\hline
\end{tabular}


Table.3 Distribution of total number of pathogens isolated

\begin{tabular}{|l|c|}
\hline Name of pathogen & Number of isolates \\
\hline E. coli & 26 \\
\hline Pseudomonas aeruginosa & 25 \\
\hline Acinetobacter baumanii & 2 \\
\hline Proteus mirabilis & 1 \\
\hline Sphingomonas paucimobilis & 2 \\
\hline Klebsiella pneumoniae & 1 \\
\hline Enterococcus faecium & 1 \\
\hline Comamonas testestroni & 1 \\
\hline Stenotrophomonas maltophilia & 1 \\
\hline Cupravidus pauculosus & 1 \\
\hline Acinetobacter junii & 2 \\
\hline Aeromonas hydrophila & 1 \\
\hline Enterobacter aerogenes & 1 \\
\hline Enterococcus species & 1 \\
\hline Achromobacter xylosoxidans & 1 \\
\hline Total & 67 \\
\hline
\end{tabular}

Table.4 Percentage sensitivity pattern of common isolates identified

\begin{tabular}{|l|l|l|l|}
\hline Sr. No & Name of antibiotic & Escherichia coli & Pseudomonas aeruginosa \\
\hline 1 & Ampicillin & $3.84 \%$ & - \\
\hline 2 & Amoxycillin/clavulanic acid & $11.53 \%$ & - \\
\hline 3 & Piperacillin/Tazobactum & $19.23 \%$ & $4 \%$ \\
\hline 4 & Cefuroxime & $3.84 \%$ & - \\
\hline 5 & Ceftriaxone & $7.69 \%$ & - \\
\hline 6 & Cefoperazone/sulbactum & $30.76 \%$ & $24 \%$ \\
\hline 7 & Cefepime & $11.53 \%$ & $68 \%$ \\
\hline 8 & Ceftazidime & - & $36 \%$ \\
\hline 9 & Ertapenem & $50 \%$ & - \\
\hline 10 & Imipenem & $53.84 \%$ & $44 \%$ \\
\hline 11 & Meropenem & $42.30 \%$ & $40 \%$ \\
\hline 12 & Doripenem & - & $52 \%$ \\
\hline 13 & Amikacin & $84 \%$ & $80 \%$ \\
\hline 14 & Gentamicin & $53.84 \%$ & $40 \%$ \\
\hline 15 & Ciprofloxacin & $7.69 \%$ & $12 \%$ \\
\hline 16 & Trimethoprim/sulfamethoxazone & $57.69 \%$ & - \\
\hline 17 & Levofloxacin & - & $8 \%$ \\
\hline 18 & Tigecycline & $100 \%$ & $20 \%$ \\
\hline
\end{tabular}


The sensitivity of Pseudomonas aeruginosa to Amikacin, Doripenem and Cefepime is $80 \%$, $52 \%$ and $68 \%$ respectively.

In a study by Jose Roberto et al., in 2016, mean age of patients was 57 yrs with female preponderance. Most common isolates were E. coli (5/18) and Klebsilla sp (3/18). 3 out 12 bile samples showed multidrug resistant bacteria. They have also stated that bactibilia was related to post-operative complications. Gallstones and bactibilia were more in female due estrogenic activity. ${ }^{21}$

In a study by Fazal Manan et al., in 2014 mean age of patients was 46.13yrs with female preponderance. Sensitivity to cefuroxime, ceftriaxone, ciprofloxacin seen in more than $50 \%$. More than $50 \%$ resistance was there to amoxicillin. ${ }^{22}$

In a study by Manoj Kumar Sahu et al., in 2011, mean age was 51.3yrs, with $55.1 \%$ male patients.88/95 samples are culture positive E. coli $(\mathrm{n}=57)$ and Enterococci $(\mathrm{n}=38)$ were predominant organisms E. coli and Klebsiella were resistant to $3^{\text {rd }}$ gen cephalosporins and ciprofloxacin. High sensitivity of GNB was there Imipenem. ${ }^{23}$

In a study by Zafar Iqbal Malik et al., in 2009, age group 40 to 60 (64\%) with female preponderance was there. Most common organism isolated was $E$. coli followed by Proteus and Pseudomonas. Most of the isolates were highly sensitive to $3^{\text {rd }}$ gen cephalosporins. $^{20}$

In a study by Malini R. Capoor in 2008 Median age is $41 \mathrm{yrs}$, male female ratio is 0.48. 37/104 samples were culture positive. Most common organism isolated was E. coli (29.7\%), Klebsiella pneumonae (27\%), Salmonella enterica serovar typhi (8.1\%), Pseudomonas aeruginosa (5.4\%). The majority of Enterobacteriaceae isolates were susceptible to piperacillin -tazobactum and meropenem. Multidrug resistant GI organisms such as $P$. aeruginosa, Acinetobacter spp., S. aureus were more frequently observed in patients with acute cholecystitis with gastrointestinal aliments. ${ }^{24}$

In a study by Christian Rupp et al., in 2016, Enterococcus species was predominant (494/1150) followed by E. coli and Klebsilla spp (179/1150). GNB were sensitive to $2^{\text {nd }}$ generation cephalosporins, carbapenems. The combination of carbapenems and vancomycin was effective in seriously ill patients. MDR strains found in $11.3 \%$ of all samples. ${ }^{25}$

In an enteric fever endemic country like India, Salmonella enterica serovar typhi and $S$. paratyphi A are among the major biliary pathogens. Enteric fever persists for many years after convalescence and increases the risk of hepatobiliary malignancy. ${ }^{24}$ But in our study there is no such incidence which may be due to lesser sample size.

The high resistance of micro-organisms to susceptible antibiotics of the past may be due to widespread and indiscriminate use of antibiotics. In our institute, empiric therapy for biliary tract infection should be targeted against E. coli and Pseudomonas species. Tigecycline should be reserved for MDR isolates.

\section{Acknowledgements}

Authors are thankful to Dean, M.G.M. Medical College, Aurangabad for granting the permission for this work.

\section{References}

1. Alves JR, Silva RC, Guerra SCP, et al., Microbiological analysis of bile in patients with benign and malignant biliopancreatic diseases and its 
consequences. Arq Gastroenterol. 2016; 53(3): 156-162.

2. Bapat RD, Supe AN, Patwardhan A, Kocher HM, Parab S, Sathe MJ. Biliary sepsis: an ascending infection. Indian $\mathbf{J}$ Gastroenterol.1996; 15: 126-8.

3. Capoor M, Nair D, Khanna G, et al., Microflora of bile aspirates in patients with acute cholecystitis with or without cholelithiasis: a tropical experience. The Brazilian journal of infectious disease 2008; 12(3): 222-225.

4. Chang WT, Lee KT, Wang SR, et al., Bacteriology and antimicrobial susceptibility in biliary tract disease: an audit of 10-year's experience. Kaohsiung J Med Sci. 2002; 18: 221-8.

5. Csendes A, Becerra $M$, Burdiles $P$, Demian I, Bancalari K,Csendes P. Bacteriological studies of bile from the gallbladder in patients with carcinoma of the gallbladder, cholelithiasis, common bile duct stones and no gallstones disease. Eur J Surg. 1994; 160: 363-7.

6. Deviere J, Motte S, Dumonceau JM, et al., Septicemia after endoscopic retrograde cholangiopancreatography. Endoscopy 1990; 22: 72-75.

7. Greenberger N.J., Isselbacher K.J. Diseases of the gallbladder and bile ducts. In: Fauci S.A., Braunwald E., Isselbacher K.J., et al., (eds). Harrison's Principles of Internal Medicine. Mc Graw-Hill, New York, 1998.

8. Kiesslich R, Will D, Hahn M, et al., Ceftriaxone versus levofloxacin for antibiotic therapy in patients with acute cholangitis. Z Gastroenterol. 2003; 41: 5-10.

9. Lai EC, Mok FP, Tan ES, et al., Endoscopic biliary drainage for severe acute cholangitis. N Engl J Med 1992; 326: 1582-1586.
10. Lax AJ, Thomas W. How bacteria could cause cancer: one step at a time. Trends in Microbiol. 2002; 10: 293-9.

11. Lee DW, Chung SC. Biliary infection. Bailliere Clin Gastroenterol. 1997; 11: 707-24.

12. Malik ZI, Malik M, Salahuddin O, et al., Microflora of bile aspirates in symptomatic cholelithiasis. JRMC; 2009; 13(1): 38-40.

13. Manan F, Khan MA, Faraz A, Khan M. Frequency of common bacteria and their antibiotic sensitivity in patients with symptomatic cholelithiasis. J Postgrad Med Inst 2014; 28(2): 177-83.

14. Mattos AA, Costabeber AM, Lionço LC, Tovo CV. Multi-resistant bacteria in spontaneous bacterial peritonitis: A new step in management? World $\mathbf{J}$ Gastroenterol. 2014; 20: 14079-86.

15. Miles RS, Amyes SG. Laboratory control of antimicrobial therapy. In Collee JG, Fraser AG, Marmion BP, Simmons A, editors. Mackie and McCartney Practical Medical Microbiology. 14th edition. India Elsevier; 2007: 151-178.

16. Nath G, Gulati AK, Shukla VK. Role of bacteria in carcinogenesis, with special reference to carcinoma of the gallbladder. World J Gastroenterol. 2010; 16: 5395-404.

17. Nilsson HO, Stenram U, Ihse I, Wadstrom T. Helicobacter species ribosomal DNA in the pancreas, stomach and duodenum of pancreatic cancer patients. World J Gastroenterol. 2006; 12: 3038-43.

18. Ohdan $\mathrm{H}$, Oshiro $\mathrm{H}$, Yamamoto $\mathrm{Y}$, Tanaka I, Inagaki K, Sumimoto K, et al., Bacteriological investigation of bile in patients with cholelithiasis. Surg Today. 1993; 23: 390-5.

19. Pilgrim $\mathrm{CH}$, Groeschl RT, Christians KK, Gamblin TC. Modern perspectives on factor predisposing to the 
development of gallbladder cancer. HPB (Oxford). 2013; 15: 839-44.

20. Rico RC, Linares JRS, Polo FC, Vázquez MTP, Rojas JLV, Estévez $\mathrm{MD}$, et al., Bacteriologic findings as a prognostic factor in the course of acute cholecystitis. Rev Esp Enferm Apar Dig. 1989; 76: 465-70.

21. Rupp C, Bode K, Weiss KH, et al., Microbiological assessment of bile and corresponding antibiotic treatment. Medicine 2016 vol. 95(10).

22. Sahu M, Chako A, Dutta A, et al., Microbial profile and antibiotic sensitivity pattern in acute bacterial cholangiatis. Indian J Gasteroenterol. 2011; 30(5): 204-208.
23. Shivaprakasha S, Harish R, Dinesh KR, Karim PM. Aerobic bacterial isolates from choledochal bile at a tertiary hospital. Indian J Pathol Microbiol. 2006; 49: 464-7.

24. Sung JJ, Lyon DJ, Suen R, et al., Intravenous ciprofloxacin as treatment for patients with acute suppurative cholangitis: a randomized, controlled clinical trial. J Antimicrob Chemother. 1995; 35: 855-64.

25. Wada K, Takada T, Kawarada Y, et al., Diagnostic criteria and severity assessment of acute cholangitis: Tokyo Guidelines. J Hepatobiliary Pancreat Surg 2007; 14: 52-58.

\section{How to cite this article:}

Naik, S.D., A.S. Wyawahare and Bhalchandra, M.H. 2017. Bacterial Pathogens from Bile and their Antimicrobial Sensitivity Pattern in a Tertiary Care Hospital. Int.J.Curr.Microbiol.App.Sci. 6(12): 2942-2948. doi: https://doi.org/10.20546/ijcmas.2017.612.342 